\title{
Pathophysiological and Clinical Aspects of Chronic Rhinosinusitis: Current Concepts
}

\author{
Stephan Vlaminck ${ }^{1 *}$, Frederic Acke ${ }^{2}$, Glenis K. Scadding ${ }^{3}$, Bart N. Lambrecht ${ }^{4,5,6}$ and \\ Philippe Gevaert ${ }^{2}$ \\ ${ }^{1}$ Department of Otorhinolaryngology, Centre Hospitalier de Mouscron, Mouscron, Belgium, ${ }^{2}$ Department of \\ Otorhinolaryngology, Ghent University/Ghent University Hospital, Ghent, Belgium, ${ }^{3}$ The Royal National Throat Nose and Ear \\ Hospital, London, United Kingdom, ${ }^{4}$ Laboratory of Immunoregulation, Flemish Institute for Biotechnology, Center for \\ Inflammation Research, Ghent, Belgium, ${ }^{5}$ Department of Internal Medicine and Pediatrics, Ghent University, Ghent, Belgium, \\ ${ }^{6}$ Department of Pulmonary Medicine, Erasmus University Medical Center, Rotterdam, Netherlands
}

\section{OPEN ACCESS}

Edited by:

Sven F. Seys,

KU Leuven, Belgium

Reviewed by: Emmanuel Prokopakis, University Hospital of Crete

Heraklion, Greece

YuXu,

Renmin Hospital of Wuhan University, China

${ }^{*}$ Correspondence: Stephan Vlaminck stephan.vlaminck@gmail.com

Specialty section: This article was submitted to Rhinology,

a section of the journal

Frontiers in Allergy

Received: 15 July 2021 Accepted: 30 September 2021 Published: 27 October 2021

Citation:

Vlaminck S, Acke F, Scadding GK, Lambrecht BN and Gevaert P (2021)

Pathophysiological and Clinical Aspects of Chronic Rhinosinusitis:

Current Concepts.

Front. Allergy 2:741788.

doi: 10.3389/falgy.2021.741788
Adult chronic rhinosinusitis (CRS) is a chronic inflammation of the mucosa of the nose and paranasal sinuses. According to the latest EPOS guidelines CRS should be regarded as primary or secondary with distinction between diffuse and localized disease. Further pathophysiologic research identified different inflammatory patterns leading to the term "endotyping of CRS." The primary focus of endotyping is to define a dominant inflammatory type allowing for better orientation of therapy. The current approach proposes the differentiation between type 2 (eosinophilic) and non-type 2 inflammatory responses. In this review pathophysiological concepts of CRS will be discussed, focusing on the different inflammatory endotypes of T cells with special attention to the eosinophilic type 2 inflammatory response. The contribution of innate and adaptive immune system responses is presented. The possibility of endotyping based on sinonasal secretions sampling is brought to attention because it is indicative of corticosteroid responsiveness and available to most ENT surgeons. Furthermore, the clinical aspects of the three distinct phenotypes are analyzed in view of their characteristics, the related endoscopic findings, typical radiological imaging, histopathology findings, their relation toward allergy and obvious therapeutical implications. This overview will enable clinicians to relate pathophysiological patterns with clinical observations by explaining the different inflammatory mechanisms, hence providing a better understanding of therapy.

Keywords: chronic rhinosinusitis, nasal polyps, eosinophilia, endotyping, allergy

\section{INTRODUCTION}

Chronic rhinosinusitis (CRS) is a multifactorial inflammatory disease of the nasal and paranasal mucosae presenting with a variety of symptom combinations. Chronic rhinosinusitis may be used to describe conditions ranging from unilateral single sinus disease to widespread sinonasal airway inflammation. The currently recognized definition of primary CRS refers to sinonasal inflammation in which no obvious underlying etiopathogenic event is occurring (i.e., excluding fungal ball, neoplasia, odontogenic or immunodeficiency).

Based on expert recommendations, criteria for CRS were established in the European Position Paper on Rhinosinusitis (EPOS) to sustain uniform epidemiologic studies (1). The EPOS 2012 
guidelines describe CRS as an inflammatory disorder defined by the presence of two or more cardinal symptoms [obstruction, drainage (anterior or posterior), smell loss, and facial pain or pressure] for at least 12 weeks duration, confirmed by objective evidence using sinus endoscopy or computed tomography (CT) scan. For study inclusion the guideline requires at least two of four symptoms for at least 3 months duration, one of which must be either nasal obstruction or discharge. According to the new EPOS 2020 classification CRS should now be regarded as primary or secondary, and distinction is made between diffuse and localized disease based on anatomic distribution (2).

Using this definition, epidemiological studies estimated the prevalence of CRS in Europe (10.9\%), China (8\%), and Brazil (5.5\%) (3-5). Studies in the USA, using symptom criteria alone, reported a prevalence of $11.9 \%$ resembling the European CRS frequency pattern (6). It is clear however that defining CRS on symptoms alone cannot be sustained as conditions such as odontogenic sinusitis, fungus ball, antrochoanal polyps and others may mimic sustained CRS symptoms and therefore have to be differentiated by adjunctive measures. Recent research showed that epidemiologically defined CRS is not verified by nasendoscopy and CT scan in half the subjects, so the prevalence in Europe is actually 3\% if a cut-off score $>4$ on the Lund-Mackay scale is used (7). Clinical presentation and CT scanning and/or nasal endoscopy are able to phenotype CRS patients differentiating patients with (CRSwNP) and without nasal polyps (CRSsNP) (8). The European Rhinologic Society and the American Academy of Otolaryngology, Head and Neck Surgery initiated the use of guidelines useful for medical therapy and surgery within a very mechanical understanding of sinus pathology $(1,9)$. This traditional phenotype-based classification however showed inadequate disease control after medical and surgical treatment probably because it does not mirror the underlying inflammatory disease. Further analysis of this is needed to understand the patient's responsiveness or lack of it to standard treatment.

The recent call for a Precision Medicine Concept now aims for integrated care pathways (ICPs) with treatment protocols adapted to clinical practice (10). Therefore, understanding and identification of different inflammatory types in CRS with proper biomarkers are researched and believed to influence decision making in personalized therapeutic strategies (10, 11). Three phenotypes of primary CRS have been described: allergic, eosinophilic and non-eosinophilic $(1,12)$. This more pathophysiological view initiated a new term called "endotyping of CRS" and resulted in the search for a more adequate therapy especially for severe and recurrent CRS inflammation $(8,13)$. An alternative distinction is the inflammatory type dominance, either type 2 (T2) (eosinophilic) or non-T2 (2). $\mathrm{T} 2$ can then be subdivided predominantly via $\mathrm{T}$ helper ( $\mathrm{Th}$ ) 2/allergy/immunoglobulin $\mathrm{E}$ (IgE) mechanisms and via innate mechanisms (ILCs, innate lymphoid cells) or a mixture of the two (later on in CRSwNP).

The general ENT clinician will be confronted with a subpopulation of Severe Chronic Upper Airway disease (SCUAD) resistant to classic therapy. Some of these individuals will have phenotypes such as aspirin sensitivity, allergic fungal disease or vasculitis, each with specific therapeutic possibilities. Blood tests such as total $\operatorname{IgE}$, IgE, and $\operatorname{IgG}$ to Aspergillus and anti-neutrophil cytoplasmic antibodies (ANCA) can aid to identify the latter two, whereas the former requires aspirin challenge testing. Nowadays multidisciplinary teams use molecular knowledge and precision medicine, with close followup regarding efficiency and quality control upon novel treatment options, such as biologicals (14). The therapeutic challenge especially applies to the even more complex pediatric SCUAD population in which underlying conditions such as cystic fibrosis and primary ciliary dyskinesia are in the differential diagnosis (15). In the adult population, SCUAD with nasal polyposis and $\mathrm{T} 2$ signature is the most challenging phenotype in finding a correct therapeutical rationale combining surgery with potential biologicals. Since these molecules are expensive it makes sense to identify characteristics which identify responders to each particular molecule by submitting data centrally to increase patient numbers (16). To date, this has not happened and the decision-making process for the individual CRS patient is based on careful monitoring of any improvement (17). The complexity of CRS pathology is important as correct medical and/or surgical treatment may largely be beneficial on control improvement of bronchial disease (18). Usefully selected biomarkers are not yet available for predicting a type 1 or type 3 inflammation in CRS; however testing for eosinophils in secretions is simple (19).

Pathophysiological concepts will be discussed in the next chapter, focusing on the different inflammatory endotypes of $\mathrm{T}$ cells with special attention to the eosinophilic T2 inflammatory response. This chapter is followed by an overview of the three main inflammatory sinonasal phenotypes, focusing on diffuse disease.

\section{PATHOPHYSIOLOGY}

To clarify pathophysiological aspects of CRS, some general immunological topics need to be known. Lymphocytes play an important role in the innate and adaptive immune system. Two major types can be distinguished: B lymphocytes originating from the bone marrow and $\mathrm{T}$ lymphocytes arising from the thymus. In the adaptive immune response, $\mathrm{T}$ cells are generated in the secondary lymphatic tissues to encounter antigens and become antigen-specific cells after proliferation. B cells, after being influenced by $\mathrm{T}$ cells, become antibody-secreting cells. Natural killer (NK) cells, activated by interferons (IFNs), are a third type belonging to the innate immune system and recognize changes in the major histocompatibility complex (MHC) class 1 (20). The main focus regarding CRS pathophysiology is on $\mathrm{T}$ cells.

\section{T-Cell Physiology}

$\mathrm{T}$ lymphocytes and their cytokines influence the cell-mediated immune response through activation via the $\mathrm{T}$ cell receptor (TCR) and the co-stimulatory molecule cluster of differentiation (CD) 28. Activation results in the production of interleukin (IL)4 and IL-10 facilitating T-cell/B-cell interaction. T lymphocytes can be immunophenotyped in $\mathrm{CD} 3+\mathrm{CD} 4+$ and $\mathrm{CD} 3+\mathrm{CD} 8+$ white blood cells by their cell surface identification molecules. 
$\mathrm{CD} 8+$ cells, also known as cytotoxic T (Tc) cells, recognize MHC1 molecules on the surface of infected cells and are bound to eliminate those. CD4+ cells, also known as Th cells, recognize MHC-2 molecules on the outer layer of antigen-presenting cells (B cells, macrophages and dendritic cells). When CD4+ T cells are stimulated by an antigen, further differentiation occurs with different cytokine patterns and distinct cellular function in vivo: actual importance is retained in Th1, Th2, Th17, regulatory $\mathrm{T}$ (Treg), and T follicular helper (Tfh) cells (21) (Figure 1).

\section{Different Types of Immune Responses}

Immune polarization is based on $\mathrm{T}$ cell cytokine production. The emerging linkage between adaptive and innate immune systems has led to the proposal of type 1, 2, and 3 immune responses (22). Type 1 immune responses are characterized by type 1 innate lymphoid cells (ILC1), and Tc1 and Th1 cells. The crucial role of this type 1 immune response is to deal with intracellular microbes, protozoa and viruses (23). The activation of ILC1, Tc1, and Th1 cells will induce the production of type 1 cytokines IFN- $\gamma$ and tumor necrosis factor (TNF)- $\alpha$ resulting in the activation of mononuclear phagocytes loaded with potent cytotoxic molecules (22). Type 2 immune responses implicate ILC2s, Tc2, and Th2 cells responsible for the production of IL4, IL-5, and IL-13 cytokines. Type 2 plays an important role in parasite infection and induces allergic diseases with important contribution of eosinophilic cells, IgE production and goblet cell hyperplasia $(22,24)$. Type 3 immune responses are currently associated with cytokines IL-17 and IL-22 and controlled by IL3, Tc17 cells, and Th17 cells. Their role is believed to facilitate immune responses opposing extracellular bacteria and fungi (22). As an overview, CD4+ (Th) and CD8+ (Tc) cells with their cytokines in CRS are described below.

Th1 cells: these cells are mainly activated by intracellular pathogens. Bacterial and viral products are bound to Toll like receptors (TLR) on antigen presenting cells (APC). Hence dendritic cells will secrete IL-12 cytokines leading to the production of typical Th1 cytokines: IL-2, IFN- $\gamma$, and TNF- $\beta$ expressing a dominant neutrophil pattern.

Th2 cells: during a type 2 immune response Th2 cells produce key cytokines IL-4, IL-5, IL-9, and IL-13, which induce antibody class switching to immunoglobulin (Ig)E and IgG1, and enhance the recruitment of inflammatory cells (predominantly eosinophils, basophils and mast cells). Goblet cell hyperplasia is stimulated and mucus production is induced. Th2 response is essential to fight parasitic infections, but also promotes allergic disease and asthma.

Th17 cells: implication of Th17 cells is considered as an immediate response to extracellular bacteria and fungi. The production of IL-17 and IL-22 cytokines may cause chronic inflammatory disease and autoimmune pathology when dysregulation is present.

Tfh cells: Tfh cells are recognized important in regulating B cells to support antibody response. IL-21 is considered the signature cytokine.

Treg cells: the two cytokines mainly associated with Tregs are IL-10 and tumor growth factor (TGF)- $\beta$. Tregs secrete these cytokines and use them to carry out a suppressive function on the immune system. It has shown importance in controlling Th2 responses. Lacking those cells may allow further development of asthma and allergy, as well as autoimmune diseases (25).

Th9 cells: IL-9 has been identified in a subset of T cells distinct from Th2 cells. The production of IL-9 requires the combination of TGF- $\beta$ (which also promotes Tregs) and IL-4 (known to induce Th2 cells). Interestingly, Th9 cells, which are strongly associated with the immunopathology of asthma, also produce IL-10. IL-9 seems important in promoting mucus production and activation of mast cells as well as eosinophils (25).

Th22 cells: Th22 cells represent a recent separate Th subset and are closely related to Th17 cells. They predominantly produce the cytokine IL-22 and were initially associated with immunopathology of skin diseases. Recent evidence indicates that IL-22 plays an important role

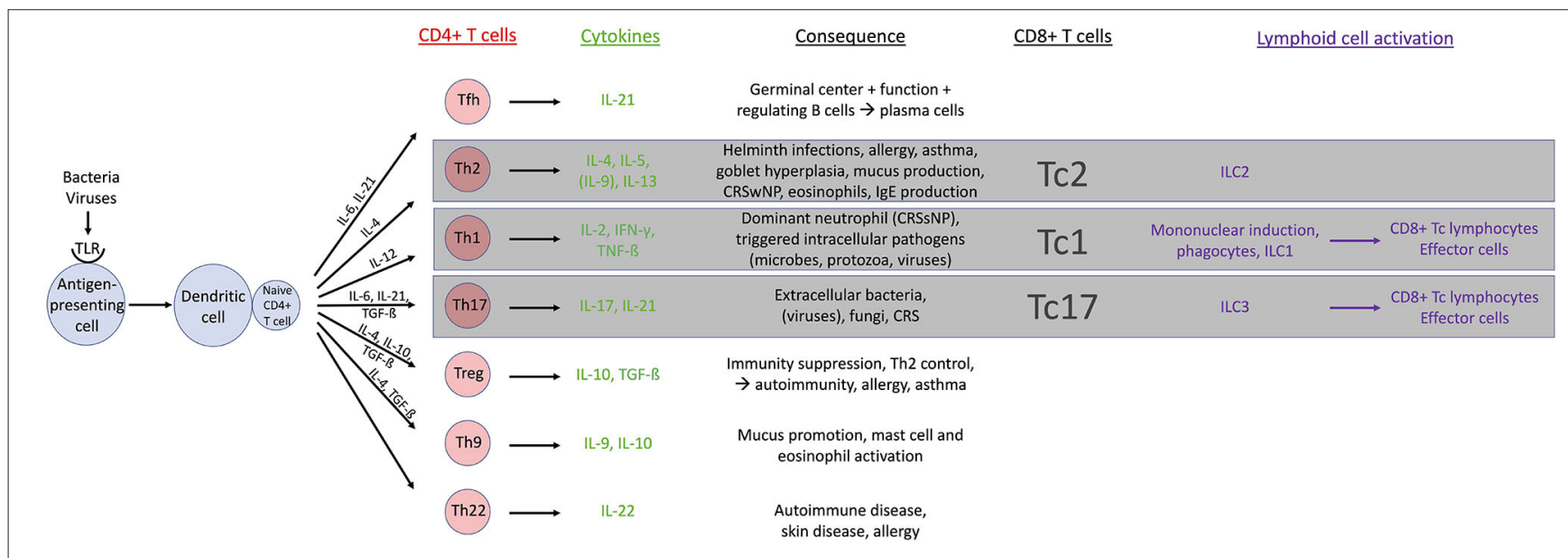

FIGURE 1 | Overview of T cell physiology. CD, cluster of differentiation; CRS, chronic rhinosinusitis; CRSsNP, CRS without nasal polyps; CRSwNP, CRS with nasal polyps; IFN, interferon; IgE, immunoglobulin E; IL, interleukin; ILC, innate lymphoid cell; Tc, cytotoxic T cell; Tfh, T follicular helper cell; TGF, tumor growth factor; Th, T helper cell; TLR, Toll like receptor; TNF, tumor necrosis factor; Treg, regulatory T cell. 
in the pathogenesis of autoimmune diseases and allergic diseases (25).

CD8+ cells: The CD8+ Tc lymphocytes seem to mirror the Th cell subset classification based on their transcription factor and cytokine expression patterns forming counterparts toward the CD4+ cell line namely Tc1, Tc2 and Tc17 cells $(24,26)$.

A large heterogeneity in CRS immune polarization is seen worldwide as the immune responses vary across different geographic areas and populations with distinct racial backgrounds (27-30). Immune responses toward type 1 , type 2, and type 3 directions can define certain endotypes and may therefore influence clinical manifestations of CRS pathology (31). CRSwNP and CRSsNP nowadays may be linked to inflammatory patterns associated with Th1 (type 1), Th2 (type 2), or Th17 (type 3). CRSsNP is accepted to exhibit a type 1 immune response $(28,29)$. In Europe, Caucasian patients with CRSwNP mainly demonstrate a type 2 immune response with high asthma comorbidity $(1,32,33)$, whereas in China and other East Asian countries, patients with CRSwNP show $\sim 50 \%$ less type 2 cytokine expression with less eosinophilic inflammation and lower asthma comorbidity (34). Asian patients with CRSwNP predominantly show neutrophil-biased inflammatory patterns (34). The association of type 2 immune responses with the development of nasal polyps is sustained in a clustering analysis of CRSsNP vs. CRSwNP in Caucasian patients (35).

\section{Type 2 Immune Responses and CRS}

Most European Caucasian and some Asian CRSwNP patients show increased numbers of Th2 and Tc2 cells, which could be associated with mucosal eosinophilia $(34,36)$. This type 2 immune response in CRSwNP is supported by the elevation of ILC2, the increased presence of tissue eosinophilia, a clear upregulation of IL-4, IL-5, IL-13, and local IgE, and profound tissue eosinophilia independent of atopy (37) (Figure 2).

After stimulation with innate immune-activating stimuli, cytokines, or injurious environmental agents such as proteases, epithelial cells produce thymic stromal lymphopoietin (TSLP) and sometimes IL-33 or IL-25, which activate ILC2. One example is the induction of IL-13 by IL-33 in reaction to the protease activity of Aspergillus Fumigatus (38). Epithelial cell-derived TSLP upregulates OX40 ligand (OX40L) expression on dendritic cells, and then dendritic cells initiate the differentiation of naive T cells into Th2 cells. Th2 cells, ILC2, and Tc2 cells orchestrate eosinophilic inflammation through production of type 2 cytokines. IL-4+ IL-21+ Tfh cells initiate the differentiation of B cells into plasma cells, followed by mast cells activation due to IgE, which is locally produced by plasma cells. Subsequently, mast cells can produce type 2 cytokines. Th2 inflammation can also induce monocytes and macrophage differentiation into M2 macrophages. M2 macrophages produce coagulation factor XIII-A (FXIII-A) that induces excessive fibrin deposition by cross-linking of fibrin and by antifibrinolytic pathways through binding the $\alpha 2$-plasmin inhibitor ( $\alpha 2$-PI, also known as $\alpha 2$ antiplasmin) to fibrin (39). Meanwhile, tissue plasminogen activator (t-PA) levels are lowered in Th2 inflammation, causing impaired plasmin generation, which in turn decreases fibrinolysis
(40). These events collectively result in the retention of water and the formation of edema in polyps. Th2 cytokine-mediated pendrin expression can increase mucus production. Cytokines IL-4 and IL-13 can decrease the expression of epithelial cell tight junction proteins. Neutrophil-derived oncostatin M (OSM) and eosinophil-derived DNA traps can also contribute to epithelium disruption.

Typical for the type 2 immune response is the increased production of local IgE in association with mucosal eosinophilia $(33,41)$, as well as the increased mucosal infiltration of B cells with the presence of markers of class switch recombination to IgE in CRSwNP patients (41-43). Of interest, Tfh cells may be found in germinal centers in secondary lymphoid tissue and are important to generate B cell responses. This is supported by the finding of ectopic lymphoid tissue in nasal polyps and the finding of Tfh cells in loco (44).

Literature reports Staphylococcus Aureus enterotoxins to act as antigen and superantigen inducing local IgE production (33). This could not be confirmed in the analysis of Chinese patients with eosinophilic CRSwNP (41). Polyclonal IgE antibodies have been shown to activate mast cells in nasal polyps (45-48) and IgE-mediated mast cell activation is found to be upregulated in eosinophilic nasal polyps (49). The finding of elevated infiltration of basophils in tissue of eosinophilic CRSwNP remains to be analyzed (50).

\section{Type 1 and 3 Immune Responses in CRS}

The type 1 immune response of CRSsNP expresses IFN- $\gamma$ cytokines in Caucasian patients $(28,29)$. Asian patients and patients with cystic fibrosis-related nasal polyps present with a neutrophil-related inflammation with high levels of IFN- $\gamma$ and IL-17A expression (12), the latter pointing toward a type 3 immune response. The IFN- $\gamma$ upregulation could however not be retained in a CRSsNP Chicago study suggesting a geographical variation (51).

In type 1 and type 3 immune responses environmental triggers will stimulate epithelial secretion of osteopontin (OPN) hence triggering dendritic cells to activate Th1 and Th17 cells (52) (Figure 3). Together with Tc1 and Tc17, Th1, and Th17 cells orchestrate non-eosinophilic inflammation through production of IFN- $\gamma$, IL-17A, and IL-22 (31). IFN- $\gamma$ induces apoptosis of epithelial nasal cells, disrupts tight junctions and stimulates neutrophils phagocytosis and chemotaxis $(52,53)$. IL-17A upregulates the expression of IL-36 $\gamma$ in epithelial cells, whereas the latter acts on neutrophils and further exaggerates neutrophilic inflammation by inducing IL-8 [C-X-C chemokine ligand-8 (CXCL8)] production from neutrophils (54). IL-22 induces epithelial cells to produce IL-8/CXCL8, which also acts on neutrophils. Neutrophils might produce OSM, OPN, and TGF- $\beta 2$. TGF- $\beta 2$ is supposed to be involved in fibrosis. IFN- $\gamma$ and OSM could disturb epithelial barrier function by decreasing the expression of epithelial cell tight junction proteins. IFN- $\gamma$ can induce activated but insufficient autophagy, leading to apoptosis of nasal epithelial cells. IL-17A + IL-21+ Tfh cells initiate B cell differentiation into plasma cells that produce immunoglobulins $\mathrm{G}$ and $\mathrm{A}$ (IgG and IgA). 


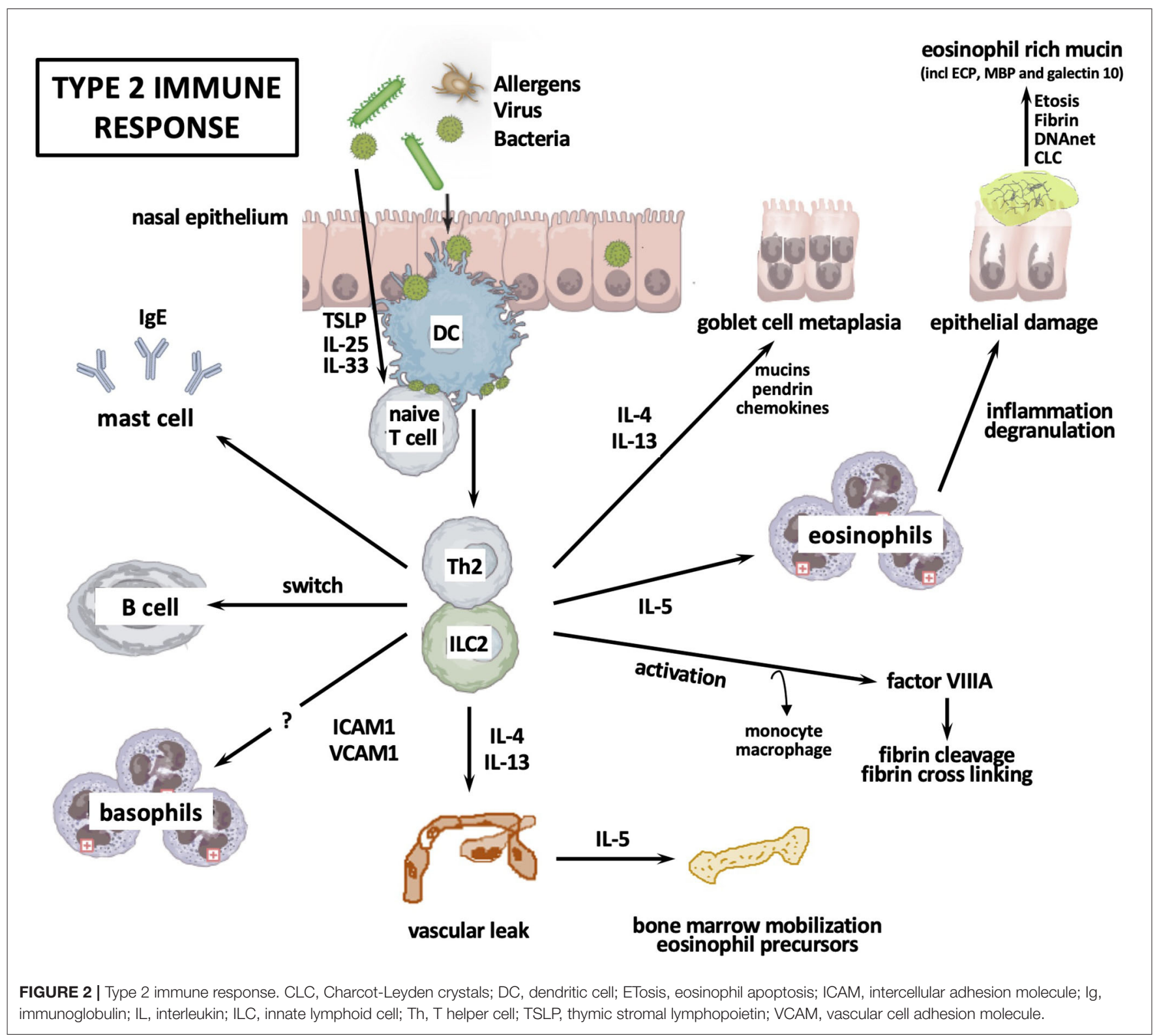

\section{Endotyping CRS - Role for Mucus Sampling}

The variety in pathophysiological mechanisms of CRS makes the achievement of a universal analysis regarding clinical characteristics, molecular biomarkers, genetics, histopathology, epidemiology and treatment response difficult. Of interest, although on a small number of patients $(n=32)$, a simplified commercially available 41-plex cytokine-chemokine array on sinonasal tissue allowed the detection of three distinct endotype signatures helpful to decide on individualized therapy (35). To date, most studies are in search of biomarkers based on tissue sampling obtained during invasive procedures (41). A more feasible and possible repetitive approach involves the sampling of mucus (55). In the cluster analysis of the latter study, inflammatory mediators pointing toward types 1,2 , and 3 inflammatory patterns were consistent with results based on tissue analysis (55). Even the presence of the Th2-associated cytokines IL-5 and IL-13 could recently be detected in sinonasal secretions by multiplex cytometric assay, suggesting possible early stratification of CRS subgroups and more personalized therapies (55). Cellular analysis of sinonasal secretions in CRSwNP patients more often shows a Th2 bound inflammation whereas the presence of eosinophilrich mucin may be considered an easy-to-obtain biomarker for predicting recurrence of CRSwNP with higher need for surgery and for predicting asthma development (56). Recent research highlights the importance of Charcot-Leyden crystals (CLC) as a relevant Th2 marker within CRS secretions 


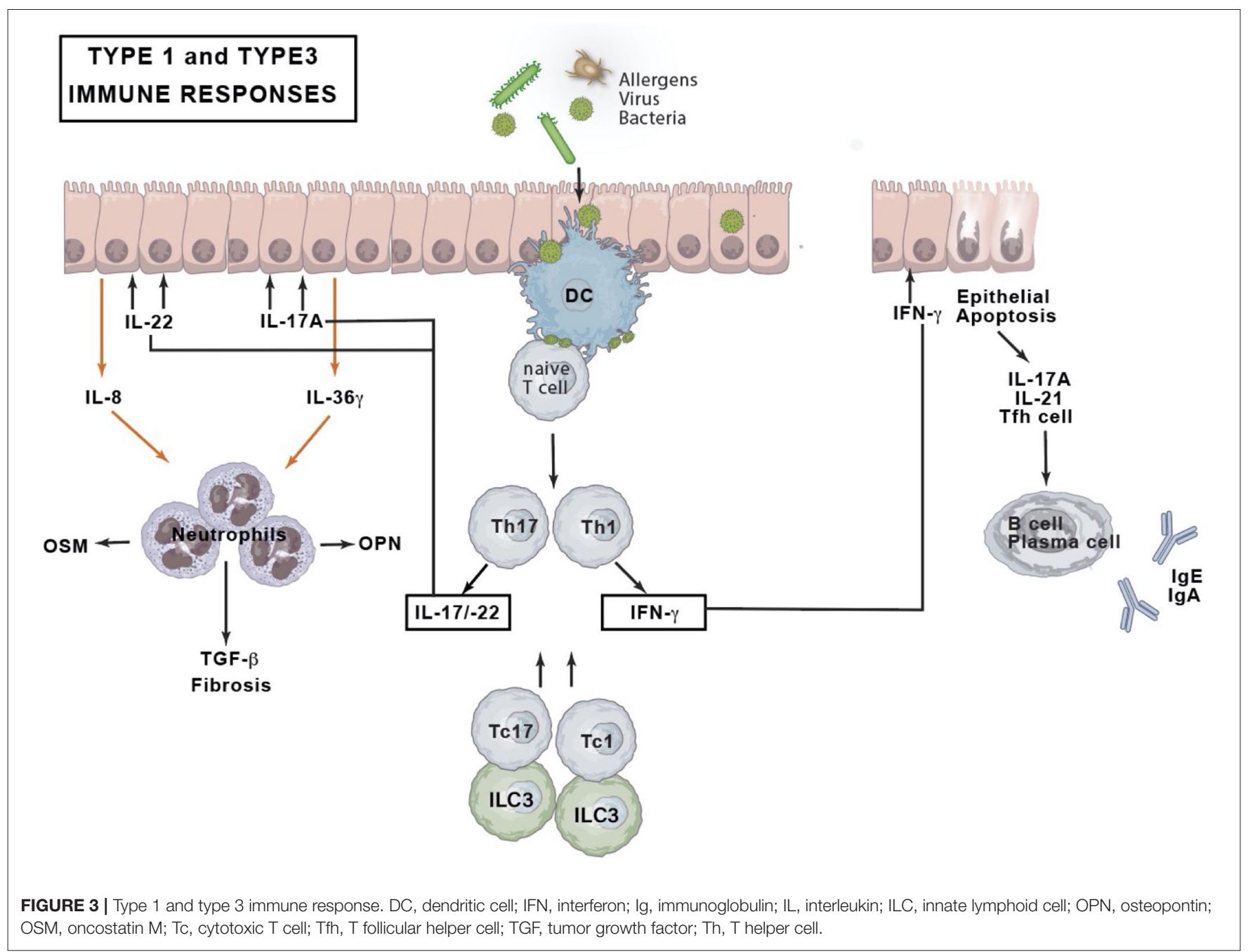

and its implications on their finding in sinonasal secretions of CRSwNP patients and in impacted bronchial secretions of eosinophilic asthma patients, opening new targets for therapeuticals (57).

In analogy with sampling of sinonasal secretions Seys et al. clearly could demonstrate in asthmatic sputum a diversity of type 2 cytokines discerning also non-type 2 cytokines concluding a priori the likeliness of type 2 vs. non-type 2 molecular asthmatic phenotypes (58).

\section{CLINICAL PRESENTATION}

Inflammatory sinonasal disease may be grossly divided in eosinophilic airway inflammation vs. non- eosinophilic inflammation. Three endotypes show a distinct T2 eosinophilic airway inflammation namely allergy, eosinophilic CRS and CRSwNP vs. a non-eosinophilic T1 inflammation pattern also present in the CRSsNP and some of the CRSwNP population. Those inflammatory patterns will be described below in addition to the concept of united airways. An overview of the characteristics of these endotypes is provided in Table 1, whereas endoscopic, CT and histologic (sinonasal secretions) images are shown in Figure 4.

Eosinophilic airway inflammation includes allergic disease such as allergic rhinitis in which the sinuses are usually minimally involved. Eosinophilic airway inflammation is also noted in CRSsNP and CRSwNP subdivisions. On the other hand we face non-eosinophilic airway inflammation in CRSsNP and in some CRSwNP subgroups.

The impact of upper airway inflammation on the lower airways is currently investigated for its impact by collecting reallife data and confirms the high disease burden in uncontrolled CRS patients, clearly impacting quality of life. Mobile technology such as Galenus Health opens a new era of real-life monitoring giving valuable clinical information about the relationship between upper and lower airways (59).

\section{Allergic Airway Inflammation Defining Characteristics}

Patients with allergic rhinitis (AR) often show an earlier onset of disease, namely at younger age $(<20)$, and although there is eosinophilic Th2 cell involvement, the disease is mainly 
TABLE 1 | Overview of the three main inflammatory sinonasal phenotypes with their characteristics (CRS, chronic rhinosinusitis).

\begin{tabular}{|c|c|c|c|}
\hline Phenotype & Allergic rhinitis & Eosinophilic CRS & Non-eosinophilic CRS \\
\hline Type of secretions & Watery secretions & Thick tenacious mucin & Discolored secretions \\
\hline Appearance of eosinophilic cells & Intact eosinophilic cells & Necrotic eosinophilic cells (ETosis) & Mainly neutrophilic cells (NTosis) \\
\hline Charcot-Leyden crystals (CLC) & No CLC & CLC present & No CLC \\
\hline Appearance of granules & No granules, no proteins & Granule proteins & Free eosinophilic granules \\
\hline Type of cytokines & T2 cytokines & T2 cytokines & T1 cytokines \\
\hline Typical age of patients & Likely young population & Likely older population & Diverse \\
\hline IgE involvement & Evidence of IgE-mediated & IgE not necessarily present & IgE not likely \\
\hline Presence of nasal polyps & Nasal polyposis not likely & Nasal polyposis likely & (Small) nasal polyps possible \\
\hline State of mucosal lining & No damage of mucosal lining & Possible mucosal damage & Possible mucosal damage \\
\hline Presence of hyphae & No hyphae & Hyphae possible & Hyphae not likely \\
\hline Presence of major basic protein (MBP) & No MBP & MBP present & MBP not likely \\
\hline CT appearance & Typical black halo on CT & Possible CT hyperattenuation & Atypical sinusitis on CT \\
\hline Presence of asthma & Asthma with early onset & Late-onset asthma, eosinophilic & Atypical asthma \\
\hline Possibility of oral steroids & Oral steroids rarely & Oral steroids more frequently & Oral steroids rarely \\
\hline Possibility of vaccination & Possible vaccination & Vaccination rarely & No vaccination considered \\
\hline Standard oral therapy & Anti-allergic therapy & Steroids, monoclonal antibodies & Antibiotics \\
\hline Typical evolution & Tendency to disappear with age & Tendency to aggravate with age & Aggravation with age (multifactorial) \\
\hline Persistence of disease & Restricted lifetime pathology & Lifetime pathology & Multifactorial dependent lifetime \\
\hline
\end{tabular}

immunoglobulin E (IgE) driven with other signs of atopic disease. Local symptoms are more dominated by itch, sneeze, and watery rhinorrhea. The presence of hyposmia rather suggests chronic rhinosinusitis with or without nasal polyps than rhinitis (60). The symptoms remain corticosteroid responsive and might soften and disappear with age (61). There is only weak evidence supporting a connection between CRS with/without nasal polyps vs. an allergic CRS condition (62). Since sinus involvement is minimal, allergic airway inflammation should probably not be included as part of CRS but be re-designated Persistent Polypoid Allergic Rhinitis (63).

\section{Endoscopy}

In patients with AR inhaled allergens are deposited on the head of the middle turbinate with possible inflammation and edema of the mucosa. The middle turbinate edema in more advanced cases can extend to the superior turbinate and posterior nasal septum and narrow or obstruct the more lateral sinus ostia (64). However, the presence of thick eosinophilic mucin as seen in eosinophilic CRS patients is by far less common in this allergic phenotype. Even with extreme polypoid change, there is often near normal ethmoid, sphenoid and maxillary mucosa, and simple trapped mucus is mostly found at surgery (65).

\section{Radiology}

The typical "black halo" sign originally described by Lund et al. shows a central thickening of the turbinates and septum with near normal peripheral sinus mucosa and is considered typical for inhalant/IgE driven CRS (66).

\section{Histopathology}

On histopathology T2 cytokines dominate and elevated total and serum specific IgE is found. Elevated serum eosinophil count is only rarely observed and tissue sampling is performed with simple hematoxylin and eosin (H\&E) coloring (61). Of most importance, eosinophilic mucin and CLC are not found in this condition as being typical to eosinophilic CRS conditions.

\section{Allergy}

Patients with AR show higher serum specific IgE compared to other subtypes of asthma (61). A Positive skin prick test or Immunocap/radioallergosorbent test (RAST) sustains the diagnosis. Differentiation has to be made between perennial and seasonal allergic disease when therapy is required (67).

\section{Therapeutic Implications}

Current treatment guidelines provided by the Allergic Rhinitis and its Impact on Asthma (ARIA) Task Force propose a stepwise approach with medical treatment and when intractable disease is faced, immunotherapy has to be considered. Only in extreme conditions of tissue remodeling adjunctive surgery might be considered as an ultimate step $(64,67)$.

\section{Eosinophilic Airway Inflammation Defining Characteristics}

Eosinophilic upper airway pathology is an inflammatory disease based on a T2 response driven by an eosinophilic inflammation. Most of those patients show an adult-onset history mainly from 30 toward 50 years of age (68). This condition is mostly found in CRS patients with nasal polyps (CRSwNP) and is often characterized by eosinophilic inflammation with elevated levels of T2 cytokines $(69,70)$. The tissue eosinophilia in CRSwNP is frequently associated with extensive sinus disease (71), higher post-operative symptom scores (72), less improvement in both disease-specific and general quality of life (73), and 


\section{$\mathrm{T} 2$ allergic rhinitis}

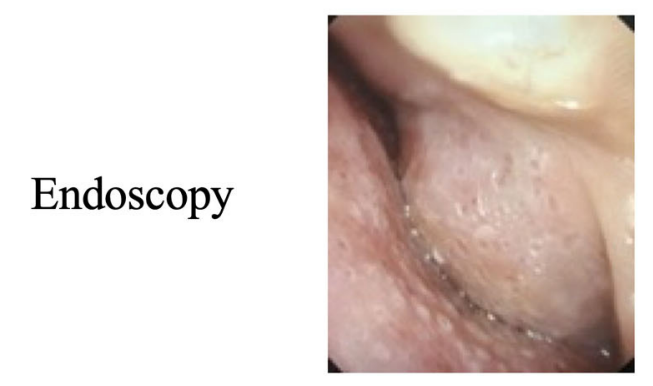

\section{CT imaging}

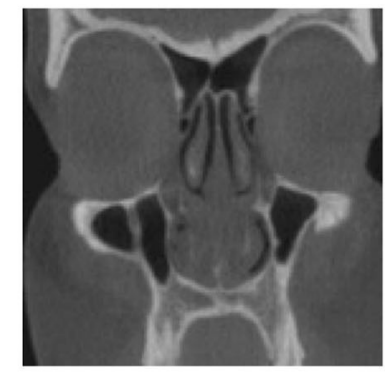

Histology
T2 eosinophilic CRSwNP
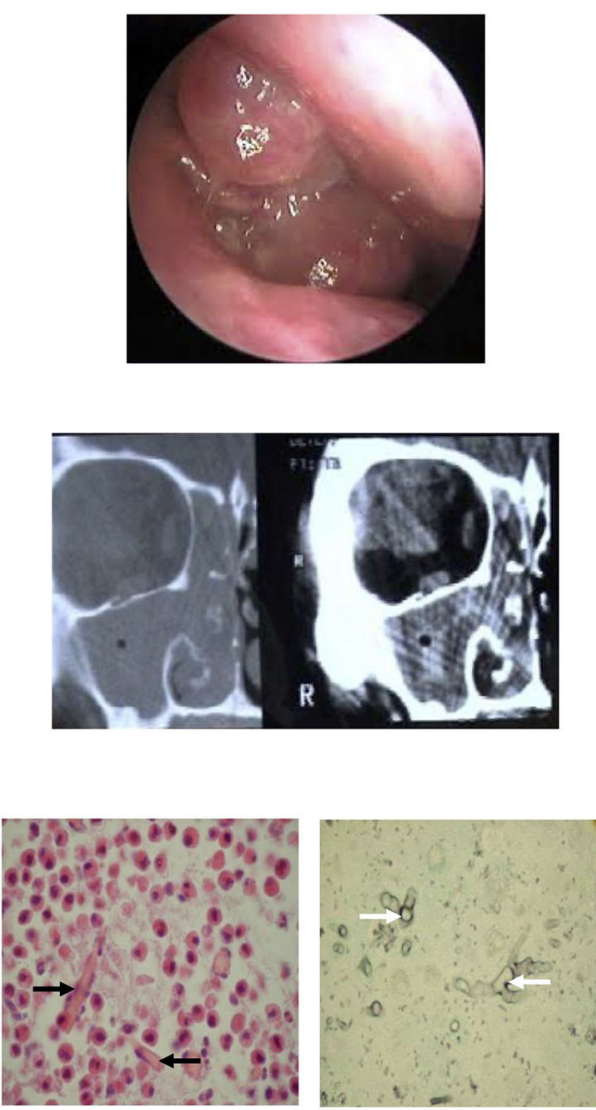

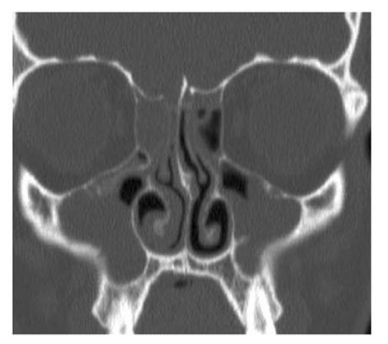

T1 CRSsNP
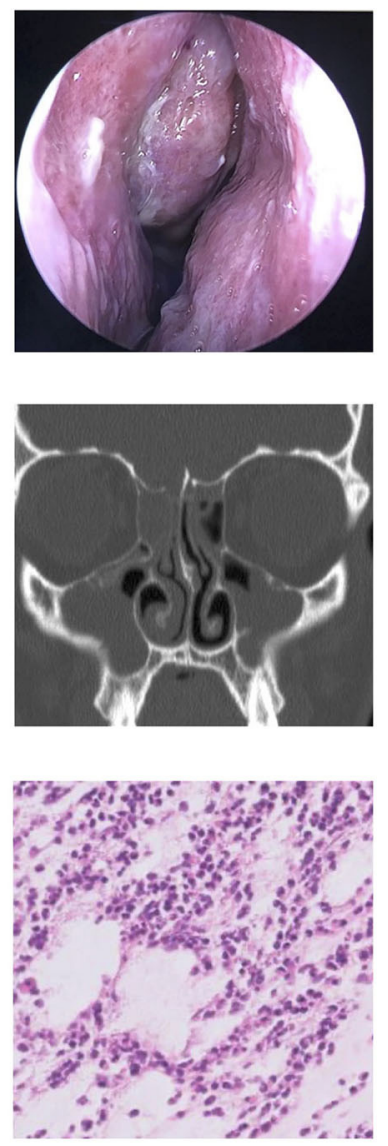

FIGURE 4 | Typical examples of endoscopic, CT and histologic (sinonasal secretions) images of the three main inflammatory sinonasal phenotypes. Images of type 2 (T2) allergic rhinitis show congestion of the nasal turbinates, normal aeration of the paranasal sinuses and mainly eosinophilic cells on a nasal smear. Images of T2 eosinophilic chronic rhinosinusitis with nasal polyps (CRSwNP) show the presence of nasal polyps on endoscopy, opacification of the paranasal sinuses on CT bone window and a hyperattenuation pattern on CT soft tissue setting. Corresponding histology findings are eosinophilic and necrotic patterns with Charcot-Leyden crystals (latter shown by black arrows) on hematoxilin/eosin staining, and fungal hyphae (white arrows) on silver staining. Images of T1 chronic rhinosinusitis without nasal polyps (CRSsNP) show opacification of the paranasal sinuses on CT and a mainly neutrophilic content in the nasal secretions.

a higher polyp recurrence rate (74-76). Moreover, CRSwNP patients with type 2 inflammation show a higher risk of lateonset asthma comorbidities, multimorbidity and recurrence of disease after surgery $(75,76)$. Noteworthy, a small number of CRS patients without nasal polyps (CRSsNP) may show a T2 signature and yield tissue and sinonasal secretions with eosinophilic infiltration (76). It is not clear if this subgroup holds the initial phase toward the development of nasal polyps. CRSwNP must be differentiated from other nasal polyp conditions like nasal choanal polyps, inverting papilloma and cystic fibrosis.

\section{Endoscopy}

At endoscopy patients will frequently present with small or already larger polyps typically protruding from the middle meatus. When attention is given the finding of tenacious eosinophil mucin may be encountered and collected on simple aspiration on consultation or at surgery. This eosinophil mucin helps further identification of a T2 bound inflammation on histopathology.

\section{Radiology}

Very often those patients show a pan-sinus opacification with evidence of secondary obstruction on CT imaging. Neoosteogenesis changes are common even in the non-operated patient. On CT soft window imaging a central density in sinuses may be present compatible with thick mucin. On T2 weighted magnetic resonance imaging (MRI) those densities may appear as a signal void (77).

\section{Histopathology}

High eosinophilic blood levels yield a positive likelihood ratio (LR) of 3.28 to predict high tissue eosinophilia but the latter is 
not significantly associated with serum allergen specific $\operatorname{IgE}(78)$. Few studies have investigated the level of mucosal eosinophil density required to meet the definition of tissue eosinophilia. Various eosinophil numbers per high power field (HPF) were used in different studies with cutoff values ranging from 5 to 350 eosinophils/HPF. A recent systematic review showed a cut off 55 eosinophils/HPF was likely to predict recurrence following surgical intervention (79). The existence of geographic, ethnic, and environmental differences suggest that specific cutoff values may be considered in different populations and regions (80). The Japanese Epidemiological Survey of Refractory eosinophilic CRS presented a new algorithm with diagnostic criteria based on scores comprising bilateral disease sites, nasal polyps, CT findings, and eosinophilia in peripheral blood. Reaching a score of 11 points was considered diagnostic for eosinophilic CRS. Significancy was reached with a cut-off value of more than $10 \%$ blood eosinophilia and tissue analysis with 70 eosinophils/HPF. Though the Japanese proportion is almost equal to that observed in Western countries $<50 \%$ of polyps in Asian patients show tissue eosinophilia (81).

The analysis of sinonasal secretions is of growing interest, as these are easy to obtain in contrast with tissue sampling. Occurrence of eosinophil apoptosis (ETosis) is shown by the presence of eosinophilic free vesicles containing toxic proteins but also by the presence of CLC as a T2 eosinophilic hallmark (82). Recently, the finding of eosinophil rich mucin (ERM) in patients with T2 bound CRSwNP was proven to be a predictor for NP recurrence after surgery, the need for revision surgery and appearance of late onset asthma (56). Very recently the importance of CLC in secretions has been stressed by mouse models and the analysis and research aiming at the dissolution of crystals opens new horizons in human treatment facilities of pulmonary and sinonasal $\mathrm{T} 2$ inflammatory disease $(57,83)$.

\footnotetext{
Allergy

A large number of these patients show no allergy at all whereas in others IgE sensitization or even a multiallergen sensitization can be found. Mechanisms with local mucosal IgE generation inducing multi-allergen sensitivity have been described (33). Staphylococcus aureus might act as a superantigen in difficult to treat patients with nasal polyps and concomitant asthma (84). CRS patients exhibiting evident allergic reaction to fungi (e.g., a positive skin prick test and/or elevated specific IgE) can still be named allergic fungal rhinosinusitis (AFRS) as this term is commonly used according to EPOS 2020 (2). AFRS is considered a clinical subtype of CRSwNP based on an innate type 2 immune response. It is characterized by the presence of eosinophilic mucin with non-invasive fungal elements; typical imaging signs of CT hyperdensity and signal void on T2 MRI images may be present. The controversy is directed at the presence of at least one positive IgE-mediated allergy to one or more fungi. This IgEbound inflammation rises the assumption of a possibly different endotype. Treatment is based on oral steroids and surgery with debridement of the sinuses. Good rationale exists for the use of biological agents targeting the eosinophilic inflammation or other type 2 responses (85-87).
}

\section{Therapeutic Implications}

Medical management has been outlined in the EPOS guidelines in a stepwise approach targeting the disease severity (1). The goal is to deliver anti-inflammatory medicine to the site of the disease with the least amount of side effects or systemic exposure. When exacerbations occur with limited burden of disease, intermittent short courses (2-3 weeks) of glucocorticosteroids (GCS) can be offered 2-3 times per year. Although medical management with intranasal and oral glucocorticosteroids has been shown to be effective in mild cases, the side effects of long-term use of GCS urges the need for surgical intervention (88). Some medical treatments of NP patients based on glucocorticoids and doxycyclin therapy show temporary success $(89,90)$.

Sinus surgery is performed in an attempt to control disease and improve the patients' symptoms and overall quality of life. Proposed surgical techniques vary from the least extensive polyp extraction to the most extensive nasalization procedures (91, 92). Due to the high recurrence rate in CRSwNP patients a tendency toward more extended approaches have been proposed for better access to the sinuses for more adequate local treatment and reducing the inflammatory load $(91,93)$. After the surgical creation of large open cavities the delivery of high-volume glucocorticoid nasal irrigations showed to be more effective vs. nasal spray in preventing endoscopic evidence of recurrence (94). Over decades, performing endoscopic surgery, it was generally accepted that stripping of the mucosa was to be avoided fearing scarring, chronic osteitis and non-functional mucosa (88). Nowadays a new concept is arising called reboot surgery based on the removal of all inflamed sinus mucosa for type 2 inflammatory CRSwNP (95).

Other therapeutic considerations are necessary as a significant number of patients continue to have upper and lower airway symptoms despite classic medical and surgical treatment. Humanized and fully human monoclonal antibodies (mAbs) such as anti-IgE, IL-5, and anti-IL-4 receptor $\alpha$ are increasingly used (96-98). Not reaching a 100\% success rate and the high cost for long-term treatment urge the need for alternative products. Evaluation of biological treatments in CRSsNP patients with signs of type 2 inflammation will be crucial in the development, together with the further search for biomarkers to identify responders to those treatments (99).

The sinonasal outcome test (SNOT)-22 score is recommended as a useful tool in symptom severity scoring by also evaluating emotional and social consequences of the condition. The objectification of eventual individual improvement by medical therapy and/or surgery can be interesting for study purposes as well as in evaluating quality of life (QoL) repercussions (100).

\section{Non-eosinophilic Airway Inflammation Defining Characteristics}

Patients with a non-eosinophilic airway inflammation may be considered as non-type 2 and are mainly characterized by neutrophils in their nasal mucosa $(31,70)$. These conditions are present in infectious rhinitis, CRSsNP and the Th17 pathway currently addressed now as type 3 immune response. In Asia, non-eosinophilic CRSwNP is frequently observed and is associated with relatively less edema and more fibrosis compared 
with eosinophilic CRSwNP (50). Of note, the presence of a mixed Th17/Th2 inflammation in CRSwNP is possible as neutrophilbiased inflammation may be demonstrated in eosinophilic nasal polyps. The combination of high levels of type 2 inflammation mediators combined with high levels of type 1 or type 3 and/or neutrophilic markers seems to predict a more severe inflammatory burden (33). Neutrophilic inflammation can be triggered by infections or chronic irritation, environmental toxins, work conditions and air pollution. Very often tissue neutrophilia is not completely controlled by inhaled GCS (101, 102).

\section{Endoscopy}

Small polyps and polypoid edema may be seen in these patients. The aspect will rather show inspissated secretions but not like eosinophil mucin. Those thick discolored secretions can obstruct the sinus outflow tracts and cause retro-obstructive retention in the paranasal sinuses with purulent postnasal drip patterns.

\section{Radiology}

This type of neutrophilic inflammation cannot be distinguished from imaging of the eosinophilic type as sinuses can be diffusely involved.

\section{Histopathology}

Tissue neutrophilia is significantly higher although some eosinophils may be present. The presence of the non-T2 cytokines in the mucus is correlated with higher culture positivity and age (103). The analysis of sinonasal secretions may contribute to depicting the presence of an active neutrophil extracellular trap (NET) mechanism with the release of chromatin (NTosis) and granule proteins that bind and kill microorganisms (104-106). In contrast ETosis depicts typical free eosinophil granules (FEG) with regulated release of toxic proteins such as major basic protein (MBP) (107).

\section{Allergy}

Overall patients will have a negative skin prick and immunocap/RAST testing, and poor clinical evidence of allergen driven symptoms.

\section{Therapeutic Implications}

When medical therapy fails patients will benefit from having sinus surgery allowing for saline washings and local application of medical therapy. This type of patients may benefit from longterm low dose macrolide immunomodulation especially CRS patients with limited response to corticosteroids $(108,109)$.

\section{United Airways}

The united airway hypothesis links the entire upper and lower airways as an interconnected system sharing the same inflammatory responses. Although Brown demonstrated the importance of sputum eosinophils in relation to corticosteroid responsiveness in asthma in 1958 (110), the concept of asthma being heterogeneous has only recently gained traction with the advent of biologicals. The term "asthma" is currently considered an umbrella diagnosis for different disorders (endotypes) and phenotypes (e.g., allergic, obesity associated, aspirin-sensitive, fungal allergic, and elderly). It is characterized by reversible airflow obstruction and its main symptoms include wheezing, shortness of breath, cough and chest tightness (111). Asthma endotypes may be broadly regarded as type 2 high or T2-low (111), similarly to CRS. In this way, it follows the heterogeneity of chronic rhinosinusitis which has been known for a long time, probably because of ease of access of the upper airways for examination and investigation.

Most Western asthma patients (78\%) have some form of upper airway disease, with similar levels of severity (112). In return, in a recent $\mathrm{UK}$ analysis the prevalence of asthma increased from control participants (10\%) over CRSsNP (21\%) to CRSwNP (47\%) and AFRS (73\%) (113). Typical associations are pollen asthma together with seasonal allergic rhinitis, and persistent rhinitis and chronic asthma. In one study $84 \%$ of severe asthma patients had sinonasal CT abnormalities. The latter correlated with eosinophils in peripheral blood and induced sputum, and with the level of exhaled NO. Sinonasal CT scores also related to lung function measurements: positively to functional residual capacity and inversely to diffusion capacity (114). Western eosinophilic CRS patients, with and without nasal polyps, frequently have asthma with shared histological and immunological features, characterized by an environment high in T2 cytokines (IL-4, IL-5, and IL-13) and in ILC2s (27, 115), suggesting a common immune process involving the upper and lower airways $(116,117)$. In contrast, T2-low asthma is characterized by neutrophilic (sputum neutrophils $>40-60 \%$ ) or paucigranulocytic (i.e., normal sputum levels of both eosinophils and neutrophils) inflammation and a lack of response to corticosteroid therapy. It has been linked to Th1 and/or Th17 cell activation and their imbalance may play a role in steroid-resistant, severe and neutrophilic asthma. The upper airway component of such conditions is not yet fully identified, and may differ geographically, since CRSwNP can be neutrophilic in the East (30). Absence of asthma may indicate a different pathophysiology, such as the co-existence of CRSsNPs and bronchiectasis, in which alpha 1 anti-trypsin should be measured.

Asthma may precede CRSwNP or parallel the sinonasal disease, however, it may also develop after CRS onset (56). The presence of asthma emphasizes the systemic nature of the underlying pathophysiology and suggests the need for consideration of the disease as a whole. CRS therapy, both medical and surgical, can improve asthma outcomes $(118,119)$. Further analysis of this relationship is required, with potentially positive effects on both upper and lower airway symptoms the use of specific monoclonal antibodies such as anti-IL5, antiIL4/13 receptor, and anti-TSLP. The pulmonologist should be encouraged to take an interest in the upper airway, and the ENT surgeon in the lower, including history-taking, examination and specific testing. Good collaboration might help in further resolving the CRS and asthma endotypes, both in an individual patient and in general.

A specific phenotype in which asthma and CRSwNP co-occur in a triad together with hypersensitivity to acetylsalicylic acid, is non-steroidal anti-inflammatory drug (NSAID) exacerbated respiratory disease (N-ERD). It may be considered a type 2 dominated inflammatory airway disorder. N-ERD is slightly 
more common in females and has an estimated prevalence of $9 \%$ in patients with asthma. The pathophysiology is considered an alteration of the cyclo-oxygenase (COX) pathway (2). The CRSwNP in N-ERD patients shows a higher rate of recurrence, and multiple sinus surgeries at younger age (120). Also asthma is more severe with more frequent exacerbations (118). Aspirin desensitization can be considered if an N-ERD patient has insufficient response to CRS treatment and/or insufficient control of asthma symptoms (121). However, discontinuation of this therapy hampers correct long-term evaluation and still questions its actual value (122). A recent retrospective study concluded that nasal polyp eosinophilia, the frequent need of oral corticosteroid courses and a history of recurrent CRSwNP surgery were consistent factors predicting uncontrolled N-ERD (123).

\section{Outcomes}

Real life data and studies may help in understanding the longterm expectations and need for close medical follow-up as we now understand in the CRSwNP phenotype. In a metaanalysis Loftus et al. found a long-term revision rate of $\sim 14$ up to $24 \%$ (based on different follow-up periods) and retained important risk factors including AFS, AERD, asthma and prior surgery (124). Over a minimal 10-year follow-up Vlaminck et al. retained a revision rate of $26 \%$ (34 of 133) stressing the importance of eosinophilic mucin presence on asthma development or aggravation and nasal polyp recurrence (56). The Utah Population Database was queried for Current Procedural Terminology codes for ESS from 1996 to 2016 by Smith et al. reporting an overall revision rate of $30 \%(n=9,177)$ over those 20 years (125). Also, the presence of comorbid asthma and allergy were significant predictors of revision surgery (125). In spite of the low number of patients Calus et al. reported a revision rate of $36.8 \%$ (14 of 38 ) over a 12 -year period, finding comorbid allergic sensitization and tissue IL-5 levels to be significant predictors (126). The help of digital health technology might be considered as it becomes more apparent some clinical

\section{REFERENCES}

1. Fokkens WJ, Lund VJ, Mullol J, Bachert C, Alobid I, Baroody F, et al. EPOS 2012: European position paper on rhinosinusitis and nasal polyps 2012. A summary for otorhinolaryngologists. Rhinology. (2012) 50:112. doi: 10.4193/Rhino50E2

2. Fokkens WJ, Lund VJ, Hopkins C, Hellings PW, Kern R, Reitsma S, et al. European position paper on rhinosinusitis and nasal polyps 2020. Rhinology. (2020) 58(Suppl. S29):1-464. doi: 10.4193/Rhin20.601

3. Hastan D, Fokkens WJ, Bachert C, Newson RB, Bislimovska J, Bockelbrink A, et al. Chronic rhinosinusitis in Europe-an underestimated disease. A GA(2)LEN study. Allergy. (2011) 66:1216-23. doi: 10.1111/j.1398-9995.2011.02646.x

4. Pilan RR, Pinna FR, Bezerra TF, Mori RL, Padua FG, Bento RF, et al. Prevalence of chronic rhinosinusitis in São Paulo. Rhinology. (2012) 50:12938. doi: 10.4193/Rhin11.256

5. Shi JB, Fu QL, Zhang H, Cheng L, Wang YJ, Zhu DD, et al. Epidemiology of chronic rhinosinusitis: results from a cross-sectional survey in seven Chinese cities. Allergy. (2015) 70:533-9. doi: 10.1111/all.12577

6. Hirsch AG, Stewart WF, Sundaresan AS, Young AJ, Kennedy TL, Scott Greene J, et al. Nasal and sinus symptoms and chronic rhinosinusitis in a population-based sample. Allergy. (2017) 72:274-81. doi: 10.1111/all. 13042 features might be associated with specific inflammatory endotype patterns (127).

\section{SUMMARY AND OUTLOOK}

CRS and its treatment are considerably better understood by improved understanding of the immune pathways behind various types of inflammation, in addition to clinical signs and symptoms of the disease. The ENT surgeon can investigate nasal secretions for eosinophilia as a guide to likely T2 inflammation and corticosteroid responsiveness. This is probably most useful in CRSsNP where it is an unexpected finding. Switching from an organ-based to a molecular-based classification in immune-mediated inflammatory diseases helps us to explain the involvement of different organs and the differences among diseases affecting the same organ. Therapeutic consequences are largely based on the responses to anti-cytokine monoclonal antibodies and might better address pathophysiological commonalities across these diseases. An approach based on signature cytokine hubs is likely to yield further insights into etiopathogenesis (128). The prediction of treatment still needs further research, and one of the challenges is co-operation to provide big data on CRS immunopathology related to various treatment outcomes. Patients themselves can participate using mobile data and a VAS score to simply evaluate their upper and lower airway symptoms and quality of life along with the therapy being used.

\section{AUTHOR CONTRIBUTIONS}

SV drafted the first version. FA and PG edited the manuscript significantly. GS and BL revised the work critically for important intellectual content. All authors made substantial contributions to the design of the work, provided approval for publication of the content, and agreed to be accountable for all aspects of the work.

7. Dietz de Loos D, Lourijsen ES, Wildeman MAM, Freling NJM, Wolvers MDJ, Reitsma S, et al. Prevalence of chronic rhinosinusitis in the general population based on sinus radiology and symptomatology. J Allergy Clin Immunol. (2019) 143:1207-14. doi: 10.1016/j.jaci.2018.12.986

8. Bachert C, Akdis CA. Phenotypes and emerging endotypes of chronic rhinosinusitis. J Allergy Clin Immunol Pract. (2016) 4:621-8. doi: 10.1016/j.jaip.2016.05.004

9. Rosenfeld RM, Piccirillo JF, Chandrasekhar SS, Brook I, Kumar KA, Kramper M, et al. Clinical practice guideline (update): adult sinusitis executive summary. Otolaryngol Head Neck Surg. (2015) 152:598609. doi: 10.1177/0194599815574247

10. De Greve G, Hellings PW, Fokkens WJ, Pugin B, Steelant B, Seys SF. Endotype-drive treatment in chronic upper airway diseases. Clin Transl Allergy. (2017) 7:22. doi: 10.1186/s13601-017-0157-8

11. Hellings PW, Fokkens WJ, Bachert C, Akdis CA, Bieber T, Agache I, et al. Positioning the principles of precision medicine in care pathways for allergic rhinitis and chronic rhinosinusitis - A EUFOREA-ARIA-EPOS-AIRWAYS ICP statement. Allergy. (2017) 72:1297-305. doi: 10.1111/all.13162

12. Cao PP, Wang ZC, Schleimer RP, Liu Z. Pathophysiological mechanisms of chronic rhinosinusitis and their roles in emerging disease endotypes. Ann Allergy Asthma Immunol. (2019) 122:33-40. doi: 10.1016/j.anai.2018.10.014

13. Akdis CA, Bachert C, Cingi C, Dykewicz MS, Hellings PW, Naclerio RM, et al. Endotypes and phenotypes of chronic rhinosinusitis: a PRACTALL 
document of the European Academy of Allergy and Clinical Immunology and the American Academy of Allergy, Asthma \& Immunology. J Allergy Clin Immunol. (2013) 131:1479-90. doi: 10.1016/j.jaci.2013.02.036

14. Vlastos I, Mullol J, Hox V, Doulaptsi M, Seys S, Hellings $\mathrm{P}$, et al. Multidisciplinary care for severe or uncontrolled chronic upper airway diseases. Curr Allergy Asthma Rep. (2021) 21:27. doi: $10.1007 / \mathrm{s} 11882-021-01004-\mathrm{z}$

15. Karatzanis A, Kalogjera L, Scadding G, Velegrakis S, Kawauchi $\mathrm{H}$, Cingi $\mathrm{C}$, et al. Int $J$ Pediatr Otorhinolaryngol. (2015) 79:965-8. doi: 10.1016/j.ijporl.2015.02.024

16. Bachert C, Han JK, Wagenmann M, Hosemann W, Lee SE, Backer $\mathrm{V}$, et al. EUROFEA expert board meeting on uncontrolled severe chronic rhinosinusitis with nasal polyps (CRSwNP) and biologics: definitions and management. J Allergy Clin Immunol. (2021) 147:2936. doi: 10.1016/j.jaci.2020.11.013

17. Vlastos I, Gkouskou K, Doulaptsi M, Karatzanis A, Prokopakis EP. Precision medicine in rhinosinusitis. Curr Allergy Asthma Rep. (2019) 19:12. doi: 10.1007/s11882-019-0850-x

18. Hellings PW, Prokopakis EP. Global airway disease beyond allergy. Curr Allergy Astma Rep. (2010) 10:143-9. doi: 10.1007/s11882-010-0107-1

19. Staudacher AG, Peters AT, Kato A, Stevens WW. Use of endotypes, phenotypes, and inflammatory markers to guide treatment decisions in chronic rhinosinusitis. Ann Allergy Asthma Immunol. (2020) 124:31825. doi: 10.1016/j.anai.2020.01.013

20. De Schryver E, Calus L, Derycke L, Bachert C, Gevaert P. Local nasal inflammation: T cells and B cells. In: Onerci TM, editor. Nasal Physiology and Pathophysiology of Nasal Disorders. Berlin; Heidelberg: Springer-Verlag (2013).

21. Spolski R, Leonard WJ. IL-21 and T follicular helper cells. Int Immunol. (2010) 22:7-12. doi: 10.1093/intimm/dxp112

22. Annunziato F, Romagnani $C$, Romagnani $S$. The 3 major types of innate and adaptive cell-mediated effector immunity. J Allergy Clin Immunol. (2015) 135:626-35. doi: 10.1016/j.jaci.2014.11.001

23. Kaech SM, Cui W. Transcriptional control of effector and memory CD8+ T cell differentiation. Nat Rev Immunol. (2012) 12:749-61. doi: 10.1038/nri3307

24. Mittrucker HW, Visekruna A, Huber M. Heterogeneity in the differentiation and function of CD8(+) T cells. Arch Immunol Ther Exp (Warsz). (2014) 62:449-58. doi: 10.1007/s00005-014-0293-y

25. Raphael I, Nalawade S, Eagar TN, Forsthuber TG, T. cell subsets and their signature cytokines in autoimmune and inflammatory diseases. Cytokine. (2015) 74:5-17. doi: 10.1016/j.cyto.2014.09.011

26. Ravindran R, Khan N, Nakaya HI, Li S, Loebbermann J, Maddur MS, et al. Vaccine activation of the nutrient sensor GCN2 in dendritic cells enhances antigen presentation. Science. (2014) 343:313-7. doi: 10.1126/science.1246829

27. Bachert C, Zhang N, Holtappels G, De Lobel L, van Cauwenberge P, Liu S, et al. Presence of IL-5 protein and IgE antibodies to staphylococcal enterotoxins in nasal polyps is associated with comorbid asthma. J Allergy Clin Immunol. (2010) 126:962-8e1-6. doi: 10.1016/j.jaci.2010.07.007

28. Van Bruaene N, Perez-Novo CA, Basinski TM, Van Zele T, Holtappels G, De Ruyck N, et al. T-cell regulation in chronic paranasal sinus disease. J Allergy Clin Immunol. (2008) 121:1435-41e1-3. doi: 10.1016/j.jaci.2008.02.018

29. Van Zele T, Claeys S, Gevaert P, Van Maele G, Holtappels G, Van Cauwenberge $P$, et al. Differentiation of chronic sinus diseases by measurement of inflammatory mediators. Allergy. (2006) 61:1280-9. doi: 10.1111/j.1398-9995.2006.01225.x

30. Wang X, Zhang N, Bo M, Holtappels G, Zheng M, Lou H, et al. Diversity of TH cytokine profiles in patients with chronic rhinosinusitis: a multicenter study in Europe, Asia, and Oceania. J Allergy Clin Immunol. (2016) 138:1344-53. doi: 10.1016/j.jaci.2016.05.041

31. Zhang N, Van Zele T, Perez-Novo C, Van Bruaene N, Holtappels G, De Ruyck N, et al. Different types of T-effector cells orchestrate mucosal inflammation in chronic sinus disease. J Allergy Clin Immunol. (2008) 122:961-8. doi: 10.1016/j.jaci.2008.07.008

32. Bachert C, Gevaert P, Holtappels G, Cuvelier C, van Cauwenberge P. Nasal polyposis: from cytokines to growth. Am J Rhinol. (2000) 14:27990. doi: $10.2500 / 105065800781329573$
33. Bachert C, Gevaert P, Holtappels G, Johansson SG, van Cauwenberge P. Total and specific IgE in nasal polyps is related to local eosinophilic inflammation. J Allergy Clin Immunol. (2001) 107:607-14. doi: 10.1067/mai.2001.112374

34. Zhang Y, Gevaert E, Lou H, Wang X, Zhang L, Bachert C, et al. Chronic rhinosinusitis in Asia. J Allergy Clin Immunol. (2017) 140:12309. doi: 10.1016/j.jaci.2017.09.009

35. Divekar R, Rank M, Squillace D, Kita H, Lal D. Unsupervised network mapping of commercially available immunoassay yields three distinct chronic rhinosinusitis endotypes. Int Forum Allergy Rhinol. (2017) 7:3739. doi: 10.1002/alr.21904

36. Derycke L, Eyerich S, Van Crombruggen K, Perez-Novo C, Holtappels G, Deruyck N, et al. Mixed T helper cell signatures in chronic rhinosinusitis with and without polyps. PLoS ONE. (2014) 9:e97581. doi: 10.1371/journal.pone.0097581

37. Miljkovic D, Bassiouni A, Cooksley C, Ou J, Hauben E, Wormald PJ, et al. Association between group 2 innate lymphoid cells enrichment, nasal polyps and allergy in chronic rhinosinusitis. Allergy. (2014) 69:115461. doi: $10.1111 /$ all.12440

38. Shaw JL, Fakhri S, Citardi MJ, Porter PC, Corry DB, Kheradmand F, et al. IL-33-responsive innate lymphoid cells are an important source of IL-13 in chronic rhinosinusitis with nasal polyps. Am J Respir Crit Care Med. (2013) 188:432-9. doi: 10.1164/rccm.201212-2227OC

39. Takabayashi T, Kato A, Peters AT, Hulse KE, Suh LA, Carter R, et al. Increased expression of factor XIII-A in patients with chronic rhinosinusitis with nasal polyps. J Allergy Clin Immunol. (2013) 132:58492.e4. doi: 10.1016/j.jaci.2013.02.003

40. Takabayashi T, Kato A, Peters AT, Hulse KE, Suh LA, Carter R, et al. Excessive fibrin deposition in nasal polyps caused by fibrinolytic impairment through reduction of tissue plasminogen activator expression. Am J Respir Crit Care Med. (2013) 187:49-57. doi: 10.1164/rccm.201207-1292OC

41. Cao PP, Zhang YN, Liao B, Ma J, Wang BF, Wang H, et al. Increased local IgE production induced by common aeroallergens and phenotypic alteration of mast cells in Chinese eosinophilic, but not non-eosinophilic, chronic rhinosinusitis with nasal polyps. Clin Exp Allergy. (2014) 44:690700. doi: $10.1111 /$ cea.12304

42. Takeda K, Sakakibara S, Yamashita K, Motooka D, Nakamura S, El Hussien $\mathrm{MA}$, et al. Allergic conversion of protective mucosal immunity against nasal bacteria in patients with chronic rhinosinusitis with nasal polyposis. J Allergy Clin Immunol. (2019) 143:1163-75.e15. doi: 10.1016/j.jaci.2018.07.006

43. Zhang YN, Song J, Wang H, Wang H, Zeng M, Zhai GT, et al. Nasal IL$4(+)$ CXCR5 $(+)$ CD4(+) T follicular helper cell counts correlate with local IgE production in eosinophilic nasal polyps. J Allergy Clin Immunol. (2016) 137:462-73. doi: 10.1016/j.jaci.2015.07.025

44. Song J, Wang H, Zhang YN, Cao PP, Liao B, Wang ZZ, et al. Ectopic lymphoid tissues support local immunoglobulin production in patients with chronic rhinosinusitis with nasal polyps. J Allergy Clin Immunol. (2018) 141:927-37. doi: 10.1016/j.jaci.2017.10.014

45. Baba S, Kondo K, Suzukawa M, Ohta K, Yamasoba T. Distribution, subtype population, and IgE positivity of mast cells in chronic rhinosinusitis with nasal polyps. Ann Allergy Asthma Immunol. (2017) 119:1208. doi: 10.1016/j.anai.2017.05.019

46. Shaw JL, Ashoori F, Fakhri S, Citardi MJ, Luong A. Increased percentage of mast cells within sinonasal mucosa of chronic rhinosinusitis with nasal polyp patients independent of atopy. Int Forum Allergy Rhinol. (2012) 2:233-40. doi: 10.1002/alr.21021

47. Takabayashi T, Kato A, Peters AT, Suh LA, Carter R, Norton J, et al. Glandular mast cells with distinct phenotype are highly elevated in chronic rhinosinusitis with nasal polyps. J Allergy Clin Immunol. (2012) 130:41020.e5. doi: 10.1016/j.jaci.2012.02.046

48. Zhang N, Holtappels G, Gevaert P, Patou J, Dhaliwal B, Gould H, et al. Mucosal tissue polyclonal IgE is functional in response to allergen and SEB. Allergy. (2011) 66:141-8. doi: 10.1111/j.1398-9995.2010.02448.x

49. Wang H, Do DC, Liu J, Wang B, Qu J, Ke X, et al. Functional role of kynurenine and aryl hydrocarbon receptor axis in chronic rhinosinusitis with nasal polyps. J Allergy Clin Immunol. (2018) 141:586600.e6. doi: 10.1016/j.jaci.2017.06.013

50. Mahdavinia M, Carter RG, Ocampo CJ, Stevens W, Kato A, Tan BK, et al. Basophils are elevated in nasal polyps of patients with chronic 
rhinosinusitis without aspirin sensitivity. J Allergy Clin Immunol. (2014) 133:1759-63. doi: 10.1016/j.jaci.2013.12.1092

51. Tan BK, Klingler AI, Poposki JA, Stevens WW, Peters AT, Suh LA, et al. Heterogeneous inflammatory patterns in chronic rhinosinusitis without nasal polyps in Chicago, Illinois. J Allergy Clin Immunol. (2017) 139:699703.e7. doi: 10.1016/j.jaci.2016.06.063

52. Eidenschenk C, Rutz S, Liesenfeld O, Ouyang W. Role of IL-22 in microbial host defense. Curr Top Microbiol Immunol. (2014) 380:21336. doi: 10.1007/978-3-662-43492-5_10

53. Gevaert P, Lang-Loidolt D, Lackner A, Stammberger H, Staudinger H, Van Zele T, et al. Nasal IL-5 levels determine the response to anti-IL-5 treatment in patients with nasal polyps. J Allergy Clin Immunol. (2006) 118:113341. doi: 10.1016/j.jaci.2006.05.031

54. Bachert C, Gevaert P, Hellings P. Biotherapeutics in chronic rhinosinusitis with and without nasal polyps. J Allergy Clin Immunol Pract. (2017) 5:15126. doi: 10.1016/j.jaip.2017.04.024

55. Turner JH, Chandra RK, Li P, Bonnet K, Schlundt DG. Identification of clinically relevant chronic rhinosinusitis endotypes using cluster analysis of mucus cytokines. J Allergy Clin Immunol. (2018) 141:18957.e7. doi: $10.1016 /$ j.jaci.2018.02.002

56. Vlaminck S, Acke F, Prokopakis E, Speleman K, Kawauchi H, van Cutsem JC, et al. Surgery in nasal polyp patients: outcome after a minimum observation of 10 years. Am J Rhinol Allergy. (2020) 35:44957. doi: 10.1177/1945892420961964

57. Persson EK, Verstraete K, Heyndrickx I, Gevaert E, Aegerter $\mathrm{H}$, Percier JM, et al. Protein crystallization promotes type 2 immunity and is reversible by antibody treatment. Science. (2019) 364:eaaw4295. doi: 10.1126/science.aaw4295

58. Seys SF, Scheers H, Van den Brande P, Marijsse G, Dilissen E, Van Den Bergh A, et al. Cluster analysis of sputum cytokine-high profiles reveals diversity in $\mathrm{T}(\mathrm{h}) 2$-high asthma patients. Respir Res. (2017) 18:39. doi: 10.1186/s12931-017-0524-y

59. Seys SF, De Bont S, Fokkens WJ, Bachert C, Alobid I, Bernal-Sprekelsen M, et al. Real-life assessment of chronic rhinosinusitis patients using mobile technology: the mySinusitisCoach project by EUFOREA. Allergy. (2020) 75:2867-78. doi: 10.1111/all.14408

60. Stanton AE, McGarry GW, Carter R, Bucknall CE. Spectrum of nasal disease in an asthma clinic: when is an ENT opinion indicated? J Laryngol Otol. (2009) 123:613-8. doi: 10.1017/S0022215108003319

61. Wenzel SE. Asthma phenotypes: the evolution from clinical to molecular approaches. Nat Med. (2012) 18:716-25. doi: 10.1038/nm.2678

62. Wilson KF, McMains KC, Orlandi RR. The association between allergy and chronic rhinosinusitis with and without nasal polyps: an evidencebased review with recommendations. Int Forum Allergy Rhinol. (2014) 4:93-103. doi: 10.1002/alr.21258

63. Scadding GK. What's in a name - is CCAD really PPAR? Rhinology. (2021). doi: 10.4193/Rhin20.629. [Epub ahead of print].

64. DelGaudio JM, Loftus PA, Hamizan AW, Harvey RJ, Wise SK. Central compartment atopic disease. Am J Rhinol Allergy. (2017) 31:22834. doi: 10.2500/ajra.2017.31.4443

65. Brunner JP, Jawad BA, McCoul ED. Polypoid change of the middle turbinate and paranasal sinus polyposis are distinct entities. Otolaryngol Head Neck Surg. (2017) 157:519-23. doi: 10.1177/0194599817711887

66. Scadding G, Lund V. Investigative Rhinology. 1st ed. London: Taylor \& Francis (2004).

67. Brozek JL, Bousquet J, Agache I, Agarwal A, Bachert C, BosnicAnticevich S, et al. Allergic rhinitis and its impact on asthma (ARIA) guidelines-2016 revision. J Allergy Clin Immunol. (2017) 140:9508. doi: 10.1016/j.jaci.2017.03.050

68. Grayson JW, Cavada M, Harvey RJ. Clinically relevant phenotypes in chronic rhinosinusitis. J Otolaryngol Head Neck Surg. (2019) 48:23. doi: 10.1186/s40463-019-0355-6

69. Cao PP, Li HB, Wang BF, Wang SB, You XJ, Cui YH, et al. Distinct immunopathologic characteristics of various types of chronic rhinosinusitis in adult Chinese. J Allergy Clin Immunol. (2009) 124:47884.e1-2. doi: 10.1016/j.jaci.2009.05.017

70. Tomassen P, Vandeplas G, Van Zele T, Cardell LO, Arebro J, Olze $\mathrm{H}$, et al. Inflammatory endotypes of chronic rhinosinusitis based on cluster analysis of biomarkers. J Allergy Clin Immunol. (2016) 137:144956.e4. doi: 10.1016/j.jaci.2015.12.1324

71. Szucs E, Ravandi S, Goossens A, Beel M, Clement PA. Eosinophilia in the ethmoid mucosa and its relationship to the severity of inflammation in chronic rhinosinusitis. Am J Rhinol. (2002) 16:131-4. doi: 10.1177/194589240201600301

72. Kountakis SE, Arango P, Bradley D, Wade ZK, Borish L. Molecular and cellular staging for the severity of chronic rhinosinusitis. Laryngoscope. (2004) 114:1895-905. doi: 10.1097/01.mlg.0000147917.43615.c0

73. Soler ZM, Sauer DA, Mace J, Smith TL. Relationship between clinical measures and histopathologic findings in chronic rhinosinusitis. Otolaryngol Head Neck Surg. (2009) 141:454-61. doi: 10.1016/j.otohns.2009.06.085

74. Oberhuber C, Ma Y, Wopfner N, Gadermaier G, Dedic A, Niggemann B, et al. Prevalence of IgE-binding to Art v 1, Art v 4 and Amb a 1 in mugwort-allergic patients. Int Arch Allergy Immunol. (2008) 145:94101. doi: $10.1159 / 000108134$

75. Van Zele T, Holtappels G, Gevaert P, Bachert C. Differences in initial immunoprofiles between recurrent and nonrecurrent chronic rhinosinusitis with nasal polyps. Am J Rhinol Allergy. (2014) 28:1928. doi: 10.2500/ajra.2014.28.4033

76. Vlaminck S, Vauterin T, Hellings PW, Jorissen M, Acke F, Van Cauwenberge $\mathrm{P}$, et al. The importance of local eosinophilia in the surgical outcome of chronic rhinosinusitis: a 3-year prospective observational study. Am J Rhinol Allergy. (2014) 28:260-4. doi: 10.2500/ajra.2014.28.4024

77. Vlaminck S, Casselman J, De Groef K, Van den Berghe I, Kuhweide R, Joniau S. Eosinophilic fungal rhinosinusitis (EFRS): a distinct CT/MRI-entity? A European experience. B-ENT. (2005) 1:73-82.

78. Ho J, Hamizan AW, Alvarado R, Rimmer J, Sewell WA, Harvey RJ. Systemic predictors of eosinophilic chronic rhinosinusitis. Am J Rhinol Allergy. (2018) 32:252-7. doi: 10.1177/1945892418779451

79. McHugh T, Snidvongs K, Xie M, Banglawala S, Sommer D. High tissue eosinophilia as a marker to predict recurrence for eosinophilic chronic rhinosinusitis: a systematic review and meta-analysis. Int Forum Allergy Rhinol. (2018) 8:1421-9. doi: 10.1002/alr.22194

80. Lou H, Zhang N, Bachert C, Zhang L. Highlights of eosinophilic chronic rhinosinusitis with nasal polyps in definition, prognosis, and advancement. Int Forum Allergy Rhinol. (2018) 8:1218-25. doi: 10.1002/alr.22214

81. Tokunaga T, Sakashita M, Haruna T, Asaka D, Takeno S, Ikeda H, et al. Novel scoring system and algorithm for classifying chronic rhinosinusitis: the JESREC Study. Allergy. (2015) 70:995-1003. doi: 10.1111/all.12644

82. Mukherjee M, Lacy P. Ueki S. Eosinophil extracellular traps and inflammatory pathologies-untangling the web! Front Immunol. (2018) 9:2763. doi: 10.3389/fimmu.2018.02763

83. Ueki S, Miyabe Y, Yamamoto Y, Fukuchi M, Hirokawa M, Spencer LA, et al. Charcot-leyden crystals in eosinophilic inflammation: active cytolysis leads to crystal formation. Curr Allergy Asthma Rep. (2019) 19:35. doi: 10.1007/s11882-019-0875-1

84. Van Zele T, Gevaert P, Watelet JB, Claeys G, Holtappels G, Claeys C, et al. Staphylococcus aureus colonization and IgE antibody formation to enterotoxins is increased in nasal polyposis. J Allergy Clin Immunol. (2004) 114:981-3. doi: 10.1016/j.jaci.2004.07.013

85. Dykewicz MS, Rodrigues JM, Slavin RG. Allergic fungal rhinosinusitis. $J$ Allergy Clin Immunol. (2018) 142:341-51. doi: 10.1016/j.jaci.2018.06.023

86. Chakrabarti A, Denning D, Ferguson B, Ponikau J, Buzina W, Kita $\mathrm{H}$, et al. Fungal rhinosinusitis: a categorization and definition of schema addressing current controversies. Laryngoscope. (2009) 119:180918. doi: 10.1002/lary.20520

87. Karp J, Dhillon I, Panchmatia R, Javer A. Subcutaneous mepolizumab injection: an adjunctive treatment for recalcitrant allergic fungal rhinosinusitis patients with asthma. Am J Rhinol Allergy. (2021) 35:256-63. doi: 10.1177/1945892420951486

88. Poetker DM, Jakubowski LA, Lal D, Hwang PH, Wright ED, Smith TL. Oral corticosteroids in the management of adult chronic rhinosinusitis with and without nasal polyps: an evidence-based review with recommendations. Int Forum Allergy Rhinol. (2013) 3:104-20. doi: 10.1002/alr. 21072

89. Pinto Bezerra Soter AC, Bezerra TF, Pezato R, Teles Abdo TR, Pilan RM, Pinna FR, et al. Prospective open-label evaluation of long-term low-dose 
doxycycline for difficult-to-treat chronic rhinosinusitis with nasal polyps. Rhinology. (2017) 55:175-80. doi: 10.4193/Rhin15.291

90. Van Zele T, Gevaert P, Holtappels G, Beule A, Wormald PJ, Mayr S, et al. Oral steroids and doxycycline: two different approaches to treat nasal polyps. J Allergy Clin Immunol. (2010) 125:1069-76.e4. doi: 10.1016/j.jaci.2010. 02.020

91. Jankowski R, Pigret D, Decroocq F. Comparison of functional results after ethmoidectomy and nasalization for diffuse and severe nasal polyposis. Acta Otolaryngol. (1997) 117:601-8. doi: 10.3109/000164897091 13445

92. Stammberger H, Posawetz W. Functional endoscopic sinus surgery. Concept, indications and results of the Messerklinger technique. Eur Arch Otorhinolaryngol. (1990) 247:63-76. doi: 10.1007/BF001 83169

93. Bassiouni A, Wormald PJ. Role of frontal sinus surgery in nasal polyp recurrence. Laryngoscope. (2013) 123:36-41. doi: 10.1002/lary. 23610

94. Thomas WW III, Harvey RJ, Rudmik L, Hwang PH, Schlosser RJ. Distribution of topical agents to the paranasal sinuses: an evidence-based review with recommendations. Int Forum Allergy Rhinol. (2013) 3:691703. doi: $10.1002 / \mathrm{alr} .21172$

95. Alsharif S, Jonstam $\mathrm{K}$, van Zele $\mathrm{T}$, Gevaert P, Holtappels G, Bachert C. Endoscopic sinus surgery for type-2 CRS wNP: an endotype-based retrospective study. Laryngoscope. (2019) 129:1286-92. doi: 10.1002/lary.27815

96. Bachert C, Mannent L, Naclerio RM, Mullol J, Ferguson BJ, Gevaert P, et al. Effect of subcutaneous dupilumab on nasal polyp burden in patients with chronic sinusitis and nasal polyposis: a randomized clinical trial. JAMA. (2016) 315:469-79. doi: 10.1001/jama.2015.19330

97. Gevaert P, Calus L, Van Zele T, Blomme K, De Ruyck N, Bauters $\mathrm{W}$, et al. Omalizumab is effective in allergic and nonallergic patients with nasal polyps and asthma. J Allergy Clin Immunol. (2013) 131:1106.e1. doi: 10.1016/j.jaci.2012.07.047

98. Gevaert P, Van Bruaene N, Cattaert T, Van Steen K, Van Zele T, Acke F, et al. Mepolizumab, a humanized anti-IL-5 mAb, as a treatment option for severe nasal polyposis. J Allergy Clin Immunol. (2011) 128:989-95.e18. doi: 10.1016/j.jaci.2011.07.056

99. Fokkens WJ, Lund V, Bachert C, Mullol J, Bjermer L, Bousquet J, et al. EUFOREA consensus on biologics for CRSwNP with or without asthma. Allergy. (2019) 74:2312-9. doi: 10.1111/all.13875

100. Hopkins C, Hettige R, Soni-Jaiswal A, Lakhani R, Carrie S, Cervin A, et al. Chronic rhinosinusitis outcome measures (CHROME), developing a core outcome set for trials of interventions in chronic rhinosinusitis. Rhinology. (2018) 56:22-32. doi: 10.4193/Rhin17.247

101. Hox V, Delrue S, Scheers H, Adams E, Keirsbilck S, Jorissen $M$, et al. Negative impact of occupational exposure on surgical outcome in patients with rhinosinusitis. Allergy. (2012) 67:5605. doi: 10.1111/j.1398-9995.2011.02779.x

102. Venkatesan N, Lavigne P, Lavigne F, Hamid Q. Effects of fluticasone furoate on clinical and immunological outcomes (IL-17) for patients with nasal polyposis naive to steroid treatment. Ann Otol Rhinol Laryngol. (2016) 125:213-8. doi: 10.1177/0003489415606449

103. Morse JC, Li P, Ely KA, Shilts MH, Wannemuehler TJ, Huang LC, et al. Chronic rhinosinusitis in elderly patients is associated with an exaggerated neutrophilic proinflammatory response to pathogenic bacteria. J Allergy Clin Immunol. (2019) 143:990-1002.e6. doi: 10.1016/j.jaci.2018. 10.056

104. Brinkmann V, Zychlinsky A. Beneficial suicide: why neutrophils die to make NETs. Nat Rev Microbiol. (2007) 5:577-82. doi: 10.1038/ nrmicrol710

105. Fuchs TA, Abed U, Goosmann C, Hurwitz R, Schulze I, Wahn V, et al. Novel cell death program leads to neutrophil extracellular traps. J Cell Biol. (2007) 176:231-41. doi: 10.1083/jcb.200606027

106. Kaplan MJ, Radic M. Neutrophil extracellular traps: doubleedged swords of innate immunity. J Immunol. (2012) 189:268995. doi: 10.4049/jimmunol.1201719

107. Ueki S, Melo RC, Ghiran I, Spencer LA, Dvorak AM, Weller PF. Eosinophil extracellular DNA trap cell death mediates lytic release of free secretion-competent eosinophil granules in humans. Blood. (2013) 121:2074-83. doi: 10.1182/blood-2012-05-432088

108. Oakley GM, Christensen JM, Sacks R, Earls P, Harvey RJ. Characteristics of macrolide responders in persistent post-surgical rhinosinusitis. Rhinology. (2018) 56:111-7. doi: 10.4193/Rhin17.049

109. Oakley GM, Harvey RJ, Lund VJ. The role of macrolides in chronic rhinosinusitis (CRSsNP and CRSwNP). Curr Allergy Asthma Rep. (2017) 17:30. doi: 10.1007/s11882-017-0696-Z

110. Brown HM. Treatment of chronic asthma with prednisolone; significance of eosinophils in the sputum. Lancet. (1958) 272:1241-50. doi: 10.1016/S0140-6736(58)91385-0

111. Kuruvilla ME, Lee FE, Lee GB. Understanding asthma phenotypes, endotypes, and mechanisms of disease. Clin Rev Allergy Immunol. (2019) 56:219-33. doi: 10.1007/s12016-018-8712-1

112. Corren J. Allergic rhinitis and asthma: how important is the link? J Allergy Clin Immunol. (1997) 99:781-6. doi: 10.1016/S0091-6749(97) 70127-1

113. Philpott CM, Erskine S, Hopkins C, Kumar N, Anari S, Kara N, et al. Prevalence of asthma, aspirin sensitivity and allergy in chronic rhinosinusitis: data from the UK national chronic rhinosinusitis epidemiology study. Respir Res. (2018) 19:129. doi: 10.1186/s12931-018-0823-y

114. ten Brinke A, Grootendorst DC, Schmidt JT, De Bruïne FT, van Buchem MA, Sterk PJ, et al. Chronic sinusitis in severe asthma is related to sputum eosinophilia. J Allergy Clin Immunol. (2002) 109:6216. doi: $10.1067 /$ mai.2002.122458

115. Steinke JW, Borish L. Chronic rhinosinusitis phenotypes. Ann Allergy Asthma Immunol. (2016) 117:234-40. doi: 10.1016/j.anai.2016. 06.006

116. Braunstahl GJ, Overbeek SE, Kleinjan A, Prins JB, Hoogsteden HC, Fokkens WJ. Nasal allergen provocation induces adhesion molecule expression and tissue eosinophilia in upper and lower airways. J Allergy Clin Immunol. (2001) 107:469-76. doi: 10.1067/mai.2001.113046

117. Ponikau JU, Sherris DA, Kephart GM, Kern EB, Gaffey TA, Tarara JE, et al. Features of airway remodeling and eosinophilic inflammation in chronic rhinosinusitis: is the histopathology similar to asthma? J Allergy Clin Immunol. (2003) 112:877-82. doi: 10.1016/j.jaci.2003. 08.009

118. Kowalski ML, Agache I, Bavbek S, Bakirtas A, Blanca M, Bochenek $\mathrm{G}$, et al. Diagnosis and management of NSAID-Exacerbated Respiratory Disease (N-ERD)-a EAACI position paper. Allergy. (2019) 74:28-39. doi: 10.1111/all.13599

119. Ragab S, Scadding GK, Lund VJ, Saleh H. Treatment of chronic rhinosinusitis and its effects on asthma. Eur Respir J. (2006) 28:6874. doi: 10.1183/09031936.06.00043305

120. DeConde AS, Mace JC, Levy JM, Rudmik L, Alt JA, Smith TL. Prevalence of polyp recurrence after endoscopic sinus surgery for chronic rhinosinusitis with nasal polyposis. Laryngoscope. (2017) 127:5505. doi: 10.1002/lary.26391

121. Cortellini G, Caruso C, Romano A. Aspirin challenge and desensitization: how, when and why. Curr Opin Allerg Clin Immunol. (2017) 17:24754. doi: 10.1097/ACI.0000000000000374

122. Laulajainen-Hongisto A, Turpeinen H, Vento SI, Numminen J, Sahlman J, Kauppi P, et al. High discontinuation rates of peroral ASA treatment for CRSwNP. A real-world multi-center study of $171 \mathrm{~N}$-ERD patients. J Allergy Clin Immunol Pract. (2020) 8:3565-74. doi: 10.1016/j.jaip.2020.06.063

123. Lyly A, Laulajainen-Hongisto A, Turpeinen H, Vento SI, Myller J, Numminen J, et al. Factors affecting upper airway control of NSAIDexacerbated respiratory disease: a real-world study of 167 patients. Immun Inflamm Dis. (2021) 9:80-9. doi: 10.1002/iid3.347

124. Loftus CA, Soler ZM, Koochakzadeh S, Desiato VM, Yoo F, Nguyen SA, et al. Revision surgery rates in chronic rhinosinusitis with nasal polyps: meta-analysis of risk factors. Int Forum Allergy Rhinol. (2020) 10:199207. doi: 10.1002/alr.22487

125. Smith KA, Orlandi RR, Oakley G, Meeks H, Curtin K, Alt JA. Long-term revision rates for endoscopic sinus surgery. Int Forum Allergy Rhinol. (2019) 9:402-8. doi: 10.1002/alr.22264

126. Calus L, Van Bruaene N, Bosteels C, Dejonckheere S, Van Zele T, Holtappels $\mathrm{G}$, et al. Twelve-year follow-up study after endoscopic sinus surgery in 
patients with chrnoic rhinosinusitis with nasal polyposis. Clin Transl Allergy. (2019) 9:30. doi: 10.1186/s13601-019-0269-4

127. Stevens WW, Peters AT, Tan BK, Klinger AI, Poposki JA, Hulse KE, et al. Associations between inflammatory endotypes and clinical presentations in chronic rhinosinusitis. J Allergy Clin Immunol Pract. (2019) 7:281220.e3. doi: 10.1016/j.jaip.2019.05.009

128. Schett G, McInnes IB, Neurath MF. Reframing immune-mediated inflammatory diseases through signature cytokine hubs. N Engl J Med. (2021) 385:628-39. doi: 10.1056/NEJMra1909094

Conflict of Interest: The authors declare that the research was conducted in the absence of any commercial or financial relationships that could be construed as a potential conflict of interest.
Publisher's Note: All claims expressed in this article are solely those of the authors and do not necessarily represent those of their affiliated organizations, or those of the publisher, the editors and the reviewers. Any product that may be evaluated in this article, or claim that may be made by its manufacturer, is not guaranteed or endorsed by the publisher.

Copyright (๑) 2021 Vlaminck, Acke, Scadding, Lambrecht and Gevaert. This is an open-access article distributed under the terms of the Creative Commons Attribution License (CC BY). The use, distribution or reproduction in other forums is permitted, provided the original author(s) and the copyright owner(s) are credited and that the original publication in this journal is cited, in accordance with accepted academic practice. No use, distribution or reproduction is permitted which does not comply with these terms. 